\title{
Overview on the China-Africa Trade Relationship
}

\author{
Magby Henri Joel Regissahui \\ Jiangxi University of Finance and Economics, Nanchang, China \\ Email: henrijoelsahui@live.fr
}

How to cite this paper: Regissahui, M.H.J. (2019) Overview on the China-Africa Trade Relationship. Open Journal of Social Sciences, 7, 381-403.

https://doi.org/10.4236/jss.2019.77032

Received: May 23, 2019

Accepted: July 27, 2019

Published: July 30, 2019

Copyright $\odot 2019$ by author(s) and Scientific Research Publishing Inc. This work is licensed under the Creative Commons Attribution International License (CC BY 4.0).

http://creativecommons.org/licenses/by/4.0/

\begin{abstract}
This paper investigates the China-Africa trade relationship which deepened since the year 2000 and became very productive in recent years. The paper scrutinizes the terms of trade, the investments made by China, and also the loans that African countries benefited from China. The analysis of the available data revealed that China has become an essential trade partner for Africa and between 2007 and 2017 mostly exported consumer goods, intermediate goods and also capital goods to Africa and imported raw materials and natural resources form African countries, with a favorable trade balance to China. From the year 2011 to 2017, South Africa appeared as the biggest trade partner of China in Africa, for the fact that it is the largest African exporter to China, followed by Angola, Congo, DR Congo, and Zambia, and also the largest importer of Chinese products, followed by Nigeria, Egypt, and Algeria. The paper also indicates that 15 African countries account for $80 \%$ of the Chinese FDI flow, led by South Africa with $19.04 \%$ of the total FDI over the period 2003-2017. Nigeria has the second position with $7.74 \%$, followed by Zambia (7.55\%), DRC (6.65\%), Algeria (6.4\%) and Sudan (5.28\%). In addition, 15 African countries totalize $83 \%$ of the Chinese loans, with Angola in the first position with $29.89 \%$ of the total amount of loans given by China between the years 2000 and 2017. Ethiopia follows with 9.58\%, then Kenya (6.84\%) and Congo (5.18). The study recommends the diversification of export partners for some African countries that highly rely on exporting to China, encourages intra African trade as a diversification solution, and calls for more intra industry trade between China and African countries.
\end{abstract}

\section{Keywords}

China-Africa Trade, Chinese FDI, Loans from China

\section{Introduction}

As a major actor of the world trade, China plays a vital role in the world econo- 
my exporting goods to every corner of the world which creates wealth and social welfare in several countries around the world. The key factor of the Chinese economy is a trade which significantly changed the living conditions of the population of China, with impressive economic growth, infrastructure development, and education.

In 2001, China joined the World Trade Organization and this adhesion boosted the production possibilities of China that finally surpassed the United States as the world largest trading country in the year 2013. China has in recent years been involved in trade organizations and engaged in partnerships with several countries around the world. The most prolific trade partnership promoted by China is the One Belt One Road Initiative created in 2013 and accessible to all countries of the world. In 2018, China was once again the world's top exporting country, with a total of US $\$ 2.294$ trillion worth of goods shipped, of which $47.8 \%$ reached countries in Asia, 22.4\% were shipped to North America, $19.1 \%$ to Europe and $4.21 \%$ exported to Africa, according to the International Trade Centre (2019) [1]. The trading power of China has also reached Africa, where the impact of trade with China has seemingly contributed to the increase of sub-Saharan African exports, according to Maswana (2018) [2].

China-Africa trade relationship has deepened over the years, and is illustrated by numbers of development projects financed by China in Africa, and also thousands of Chinese firms operating on the African continent. From the year 2000, China has become an important partner of the whole of Africa with investments and finance flows. During the world financial crisis in 2008, China appeared as an alternative market to the traditional importers of African's products which were experiencing a deep economic contraction that reduced their demand. Since then, China has become an essential trade partner of Africa, and in 2009, became the most important trading partner of Africa, overtaking the United States [3].

By the year 2014, China was the largest importer of goods and services from sub-Saharan Africa, impulsively helping the exports of Africa's raw materials to quintuple over the period 1995 to 2015. According to Xinhua (2018) [4], the trade volume between China and Africa soared from US\$765 million in 1978 to US $\$ 170$ billion in 2017, transiting by $\$ 10$ billion in 2000 and US $\$ 198$ billion in 2012 [5]. Xinhua (2018) [4] mentioned that from 1978 to 2017, the trade between China and Africa has increased more than 200 times, soaring from 765 million US\$ to 170 billion US\$. Also, the volume of trade reached the value of nearly US $\$ 82$ billion during the first five months of the year 2018, gaining a percentage of 17.7 every year.

Meanwhile, China appears as the first destination of export of Africa and also the origin of its largest imports. This significant increase in the volume of trade between the two sides definitely contributed to the growth encountered by Africa during recent years. China is still the most important trading partner of Africa today and is determined to remain at this position for a long period of time. The recent Summit of the Forum on China-Africa Cooperation (FOCAC) orga- 
nized in Beijing in September 2018 is a good illustration of the intentions of China towards Africa; indeed, during the summit, the Chinese president literally pledged $\$ 60$ billion to finance projects in Africa as assistance, investment, and loans [6].

Our study is a general review of the China-Africa trade which examines on the terms of trade, details the nature of products exchanged by the two sides, investigates the Chinese investments and loans in African countries, and also illustrates the recent major projects existing between China and Africa.

\section{Literature Review}

The international economic integration is one of the main economic developments affecting international trade in recent decades. Countries have become more open and closer to each other. Meanwhile, China which is the second world best economy and also the world's biggest exporter is playing an important role in the world economy and also in the world trade.

China has recently established trade partnerships with several countries from all parts of the world, including African countries. Indeed, the trade relationship between China and African countries has deepened in recent years, which led to an important increment of trade volume.

This situation has been shown in a McKinsey report that indicated Sino-African relations witnessed remarkable growth over the past decade, with bilateral trade up 20 percent and direct investment rising 40 percent annually [7].

Several researchers have analyzed the China-Africa trade relationship, but the recent findings reveal that exports to China have reduced recently due to a slowdown of the Chinese economy which shifted from manufacturing dependence to local consumption. This situation greatly affects Africa countries that essentially export to China.

Ruben Nizard (2017) mentioned that natural resources occupy 90 percent of the sub-Saharan African exports to China [8], while a diversification occurs in imports from China, illustrated by higher levels of machinery, electronics, manufactured products.

In the recent years, the Chinese economy has slowdown and is reoriented towards local consumption which has weakened the imports of commodities from Africa, which has consequently affected African countries that heavily depend on exporting to China.

According to Coface (2017) [8], crude oil is the most exported products to China, principally provided by South Sudan topping the ranking since 2011, while Angola and Congo are in second and third position. The Gambia occupies also a good position in the ranking based on wood production.

Giuseppe Crisafulli (2018) detailed Africa's most exported products by regions, as follows: In the east, the most exported goods to China are Food products such as Livestock, Coffee, and grains [9]. In the North, in Morocco and Tunisia, Ores and plastic goods have recently surpassed textiles, which were the main exports of that part of Africa. In the West, Cotton products were mainly 
exported by Mali, Benin, and Niger. In the south, Ores and other precious metals were the most exported to goods to China. More recently, China granted exporters from least developed countries benefits of preferential tariffs agreement, in order to support their exports and contribute to their economic development.

Figure 1 shows the place of China in the economy of some African countries, and it can be observed that China benefited of $99.3 \%$ of the total exports of South Sudan during the year 2017. More than half of the total exports of Angola were destinated to China during the same year, while DRC, Mauritania, and Congo exported more than $30 \%$ of their total export to China

Figure 1 supports the findings of Valentina Romei (2015) who demonstrated during the year 2014 that exports to China are very important for some African countries such as Eritrea where exports to China account for roughly $60 \%$ of the total exports. The share of exports to China is approximately $50 \%$ in countries like Congo, Angola, and Sudan [10].

Yet, it is also necessary to notify that the gradual diversification of Africa's exports, that experience increasing the transformation of raw materials which generates more value-added, and contributes to increasing the incomes of the population and creates jobs and enhances technology transfers.

Although exports to China shrink, African countries can rely on the local transformation of their natural resources and also on the Chinese aid and investment in sectors such infrastructure, energy, industry promoted by the Belt and Road Initiative which contributes to their development.

Ruben Nizard (2017) mentioned that the interests of the Chinese investors were into the African mining sector [8]. He affirmed that in 2013, China ranked first among the merger and acquisitions investors of Africa. The author cited Dealogic which stated that mining and oil sectors were estimated to 80 percent of the Chinese acquisitions in Africa.

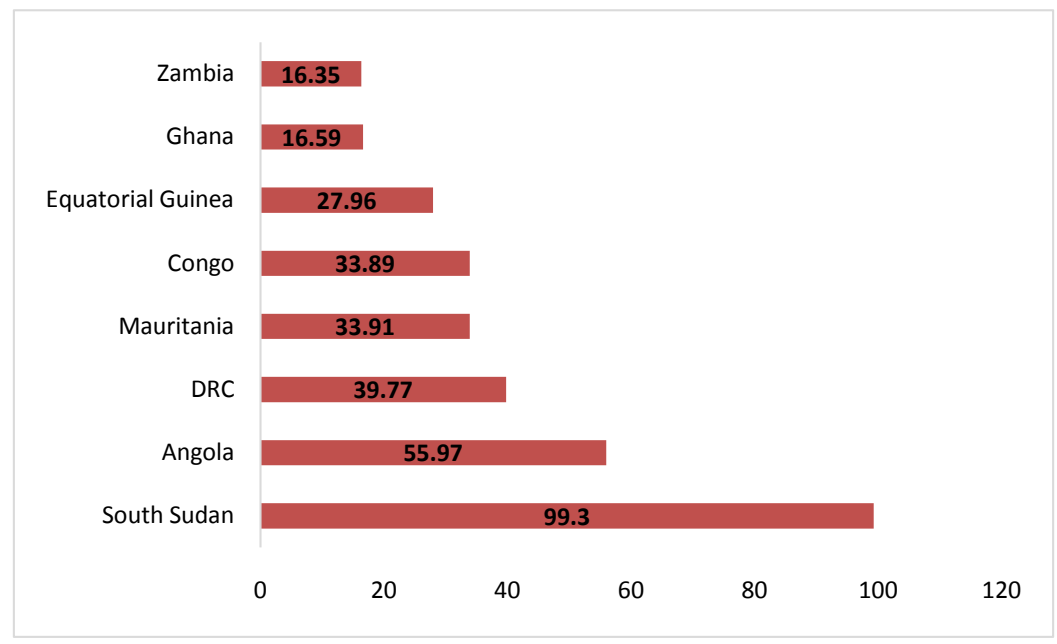

Figure 1. Share of exports to China in selected African countries for the year 2017 in percentages. Source: Data collected from International Trade Centre Statistics and computed by the author. 
However, boosted by the Belt and Road Initiative that aims to develop infrastructure which will connect African regions, ease trade and reduce trade costs, the Chinese have recently increased their investments in Africa. Chinese operating in Africa have diversified their activities from mining to manufacturing and services.

Hai and Cohen (2017) affirmed that the Chinese firms in Africa are penetrating the African market and occupy principally sectors such as manufacturing, trade, construction, and services [11]. They have generated approximately $\$ 180$ billion in revenues during the year 2017 according to Hai and Cohen (2017), adding that the more than $30 \%$ of Chinese companies in Africa operate in the manufacturing sector [11].

Yu Zheng (2016) analyzed the Chinese aid and investment in Africa over the period 2000-2013; he revealed that the top 15 African recipients cumulatively benefit of $52.1 \%$ of the total Chinese aid projects. Zimbabwe obtained the largest share of Chinese aid projects, followed by Tanzania and Ghana [12].

The findings of Yu Zheng (2016) indicated that the health sector is the major sector to which Chinese aid is allocated, accounting for $25 \%$ of the Chinese aid projects. The aid to governments and civil society accounts for $12 \%$, followed by education accounting for $10 \%$ of the total Chinese aid. projects in Africa [12].

Also, the top 15 destinations totalize $71.7 \%$ of Chinese FDI projects led by Nigeria and South Africa which are among the top trading partners of China in Africa and also the most economically powerful countries on the continent. projects in Africa over the 2000-2013 period.

In terms of FDI flows, 15 countries account for $83.4 \%$ of total FDI flows in Africa, dominated by South Africa with $20.5 \%$, followed by Nigeria (8.4\%), Algeria (8.3\%), and Zambia (8.0\%) from 2003 to 2014.

Yu Zheng (2016) presented, as illustrated in Figure 2 the repartition of the Chinese investment in Africa by sector of activity, and showed that manufacturing sector attracts over a quarter of the Chinese FDI in Africa (26.8\%), followed

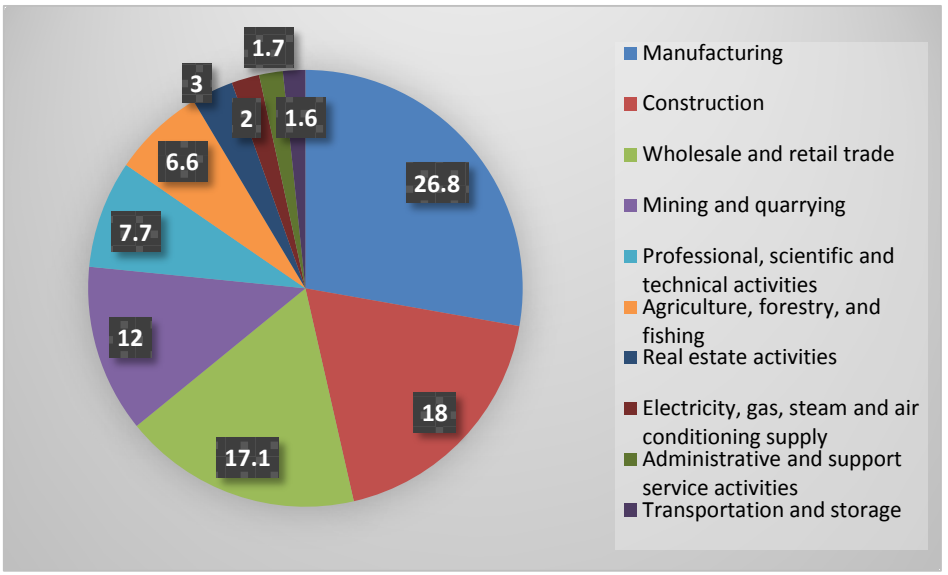

Figure 2. Chinese FDI in Africa by sector of activity from 2003 to 2014. Source: Author's computation based on the results released by Yu Zheng (2016) who collected the data from MOFCOM (2014). 
by construction (18\%), Wholesale and retail trade (17.1\%), and Mining and quarrying with (12\%). The Agriculture sector attracted similar percentages of aid and investment projects (6.5\% and 6.6\%) [12].

More recently, 10 major plans to boost cooperation between China and Africa were announced during the second FOCAC summit in South Africa (see Table $1)$.

Table 1 illustrates projects totally or partially financed by China and executed by Chinese companies which aim to boost economic development in Africa through infrastructure improvement. These infrastructure projects will generate economic activities in their area and create jobs which definitely will improve the social welfare of the local populations. The contribution of China to the development of Africa is undeniably shown through financing the above projects.

Impact of trade with China and Chinese investments in Africa

From the year 2000 which is practically the beginning of the active presence of China in Africa till date, we can assuredly affirm that China considerably contributed to the development of African countries. Several reasons support this statement.

Table 1. Major recent China-Africa infrastructure cooperation projects.

\begin{tabular}{|c|c|c|}
\hline Project & Specificity & Contractor \\
\hline $\begin{array}{l}\text { Lobito-Luau railway } \\
\text { in Angola }\end{array}$ & $\begin{array}{l}\text { 1344-km; fastest traveling speed in } \\
\text { Angola }\end{array}$ & $\begin{array}{l}\text { China Railway Construction } \\
\text { Corporation Limited }\end{array}$ \\
\hline \multicolumn{3}{|l|}{ Addis Ababa Light Rail } \\
\hline $\begin{array}{l}\text { Transit (AA-LRT) in } \\
\text { Ethiopia }\end{array}$ & $34 \mathrm{~km}$; first light railway in Africa & China Railway Group Limited \\
\hline $\begin{array}{l}\text { Kigamboni Bridge in } \\
\text { Tanzania }\end{array}$ & $\begin{array}{l}\text { 680-meter-long bridge, } 32 \text { meters wide } \\
\text { ( } \$ 135 \text { million) }\end{array}$ & $\begin{array}{l}\text { China Railway Construction } \\
\text { Engineering Group and China } \\
\text { Railway Major Bridge Group }\end{array}$ \\
\hline $\begin{array}{l}\text { Abuja-Kaduna railway } \\
\text { in Nigeria }\end{array}$ & $\begin{array}{l}186.5 \mathrm{~km} \text {; linking Abuja (the capital city) } \\
\text { and Kaduna (northwestern state) }\end{array}$ & $\begin{array}{l}\text { China Civil Engineering } \\
\text { Construction Corporation }\end{array}$ \\
\hline Ethio-Djibouti railway & $\begin{array}{l}\text { 752.7-km; linking Addis Ababa } \\
\text { (Ethiopian capital) and the port of } \\
\text { Djibouti; first modern electrified railway } \\
\text { of Africa ( } \$ 4 \text { billion) }\end{array}$ & $\begin{array}{l}\text { China Railway Group Limited } \\
\text { and China Civil Engineering } \\
\text { Construction Corporation }\end{array}$ \\
\hline $\begin{array}{l}\text { Tanzania-Zambia } \\
\text { railway }\end{array}$ & $\begin{array}{l}\text { 1860-km; revitalizing the China-Africa } \\
\text { friendship's monument built in the } \\
\text { 1970s; longest railway in sub-Saharan } \\
\text { Africa }\end{array}$ & $\begin{array}{l}\text { China Railway Construction } \\
\text { Corporation }\end{array}$ \\
\hline $\begin{array}{l}\text { Pointe Noire special } \\
\text { economic zone }\end{array}$ & $\begin{array}{l}\text { China-Africa production capacity } \\
\text { cooperation and a model project for } \\
\text { Africa's intensive development. }\end{array}$ & NA \\
\hline Garissa power plant & $\begin{array}{l}50 \text {-megawatt PV power plant; largest PV } \\
\text { power plant in East Africa; financed by } \\
\text { the Export-Import Bank of China ( } \$ 135 \\
\text { million) }\end{array}$ & $\begin{array}{l}\text { China's Jiangxi Corporation for } \\
\text { International Economic and } \\
\text { Technical Cooperation (CJIC) }\end{array}$ \\
\hline
\end{tabular}

Source: Author's computation of data collected from Xinhua (2017) (Major China-Africa infrastructure cooperation projects, Chinadaily.com [13]). 
According to Haifa Said (2018), China's development model has taken 700 million people away from poverty, estimated to 70 percent of the world poverty reduction, with long-term political stability, economic growth, governance, e-commerce, and technological and scientific innovation [14]. Now China is willing to help Africa which potentially has enough resources for better economic development.

China through its investment helped Africa to record 5.8 percent economic growth in 2007, which is its highest ever. Ayodele T. \& Sotola O. (2014) mentioned that Africa widely owes this success to Chinese investment during a crucial period of Africa's history [15].

Also, more than 10,000 Chinese companies are operating in Africa and over 90 percent of them are private businesses, according to Nan Cunhui, a member of the Standing Committee of the Chinese People's Political Consultative Conference National Committee [16].

This important number of Chinese companies in Africa created great opportunities for the development of the continent by building roads, railways, airports, ports, and energy development projects.

China Economic.net (2019) revealed that Chinese companies have also brought advanced technologies and development concepts, and also created job and generated tax to the local governments, as an example, can be cited the industrial park in Egypt, where more than 95 percent of the employees are locals and whose professional and managerial skills have been developed [17].

According to Chi Jianxin, chairman of the China-Africa Development Fund, China will invest 4.5 billion \$U.S. in 91 projects in 36 African countries, targeting production capacity, infrastructure, and agriculture sectors reported Xinhua (2017) [18].

The specificity of this investment is the fact it raises the development capacity of African countries without augmenting their debt burden.

In addition, the prices and quality of Chinese products generally satisfy the demand of the African market. Africans are mostly low-income people and their purchasing power is now high. The Chinese have perfectly learned and mastered the market to the point where they strictly offer products that fit into income level in each African country. Trade with China has significantly impacted the lives of the African population in recent years. As an example, the mobile phones market in Africa which influenced by the low prices of the Chinese phones drove down the price of other countries' suppliers and gave access to mobile to millions of African. The case is the same for computers imported at a cheaper price from China which improved the living conditions of African people, giving access to a computer to most people in Africa, which was once considered as exclusively for the rich in African countries.

Also, access to solar energy that brings light in remote areas of Africa makes the living conditions of these people more pleasant. The examples show that China greatly contributed to the development of African countries. 


\section{Terms of Trade between Africa and China}

Since the year 2000, and mainly boosted by the first Summit of the Forum on China-Africa Cooperation (FOCAC) which representatives from 44 countries and 17 international and regional organizations joined., economic nexus between China and Africa have drastically increased over the years. During the world financial crisis of 2008, China appeared as an alternative market to the traditional importers of African's products which were experiencing a deep economic contraction that reduced their demand. Since then, China has become an essential trade partner of Africa until now. Since 2014, the commodity prices have decreased on international markets which seriously affected the value of African exports to China, although the steady evolution of African imports from China. This situation is shown in Figure 3 that pictures the evolution of total trade between China and Africa, the African exports to China and also the Chinese exports to Africa from 2004 to 2018.

Nonetheless, it was revealed that Africa's exports to China quintupled over the period 1995-2015, which has definitely contributed to African countries' development. Also, Xinhua (2018) mentioned that from 1978 to 2017, the China-Africa trade has increased more than 200 times, which is an impressive evolution soaring from 765 million US\$ to 170 billion US\$ [4].

\section{China-Africa Trade Balance}

The observation of Figure 4 shows that the trade balance was sensibly neutral from 2004 to 2013, and from the year 2014 Africa encountered a large deficit due to the commodity prices' drop on international markets. This situation really affected the value of African exports to China, as outlined by the China-Africa Research Initiative (2018) [20]. Another reason is the change observed in the growth model of China, reducing outward investments and focusing on its domestic market which is immensely supported by its huge population that has considerably curbed its African imports. However, during the year 2018, the trade balance has become positive, which indicates probable stability in international commodities markets.

\section{Trading Partners of Africa}

Africa is a continent that has been colonized by countries from the west, and most countries of Africa have strong links with their former colonial masters. Colonization heritages, culture, and links which are quite strong due to the long years of cohabitation with the colonial masters and eventual consequences that resulted from that epoch, such as friendships, families, political connections, and strong attachments with the locals have directed trade and businesses in most countries of Africa. The presence of westerners long ago before China is undeniably an advantage that China didn't have, but gradually China has learned the African way of doing business and finally took the lead as Africa's largest trading 
partner, surpassing the United States in 2009. Africa's exports to China keep increasing, as well as the importance of China for the economic development of African countries. Western countries are still important for African economies as they mostly operate in groups and benefit of strong political linkages in African countries and huge enterprises established in Africa for decades. Taken from an individual perspective, China is the largest trading partner, but from the organization's point of view, the European Union dominates trade with Africa.

The observation of Figure 5 shows that the European Union as a group is the main destination of African exports, followed by Africa which describes the level of intra trade between African countries. African exports to the United States of America have considerably decreased from the year 2014 to 2018. China appears as the main destination of African exports to a single country. The figure shows that exports to China have gradually increased since the year 2000, and became important from the year 2008 which was the period of the global financial crisis, as mentioned in the literature.

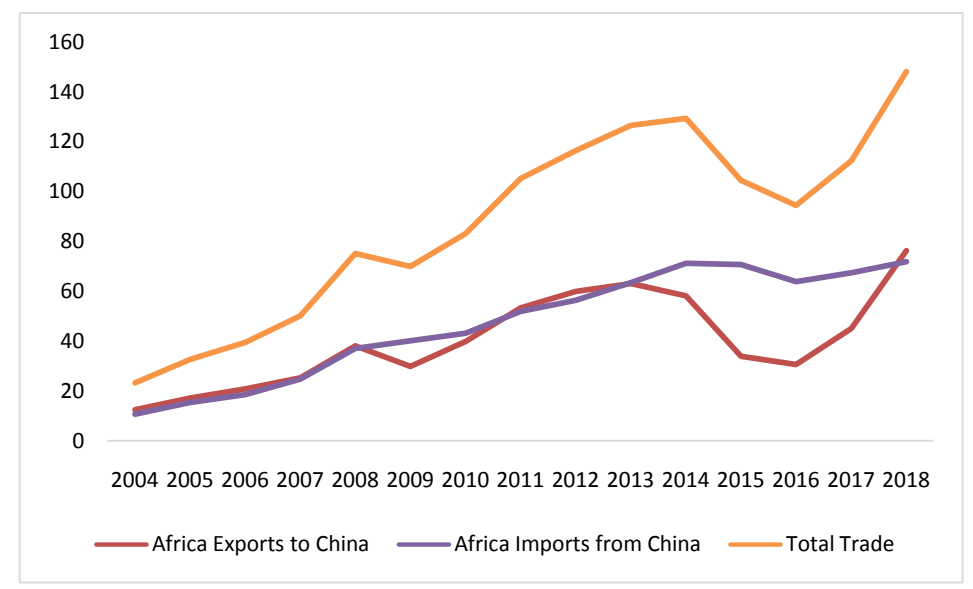

Figure 3. Total trade between China and Africa in US\$ Billion. Source: International Monetary Fund (IMF) Direction of Trade Statistics (DOTS) (2019) [19].

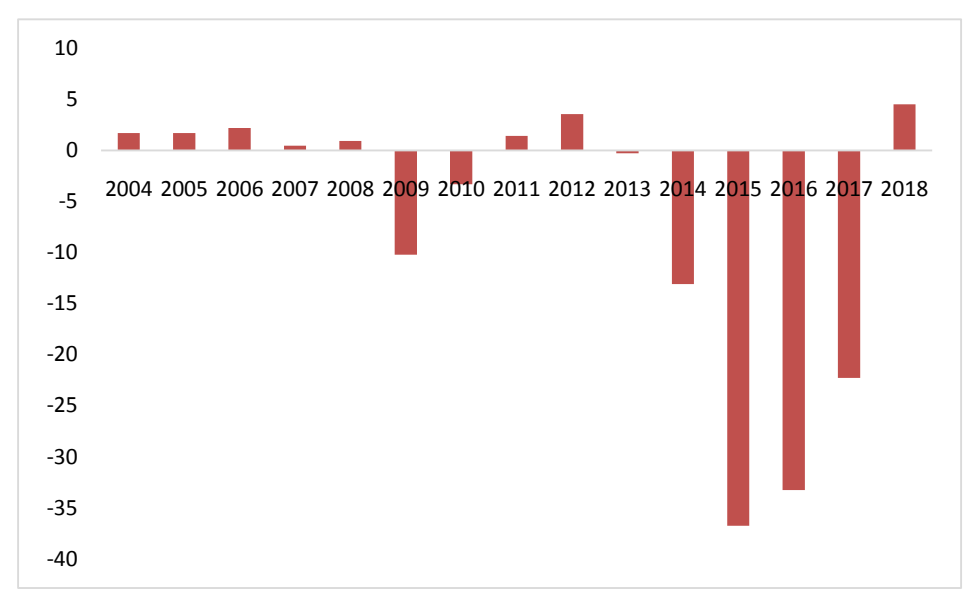

Figure 4. Trade balance between Africa and China in Billion US\$ from 2004 to 2017. Source: International Monetary Fund (IMF) Direction of Trade Statistics (DOTS) (2019). 


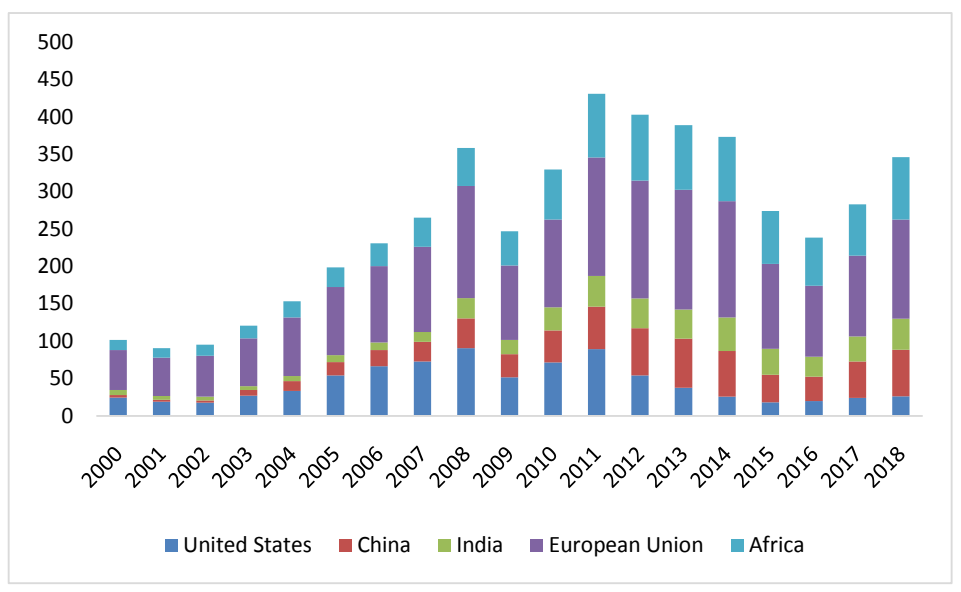

Figure 5. Africa's exports by partner (US\$ Billion). Source: Author's computation of data collected from Direction of Trade Statistics (IMF).

Figure 5 shows that African countries import much more from the European Union, which can be explained by historical and colonial reasons, which create strong links between African countries and countries from Europe. The level of intra Africa is once illustrated in this figure attesting an acceptable level of trade between African countries. China is according to the figure is the main origin of African imports for successive years after overtaking the United States of America in 2009. Meanwhile, African imports from the United States of America haven't really increased over the years and remain lower than African imports from China.

Figure 6 clearly shows that in recent years Africa imports more from China, which makes China the largest country exporting to Africa. However, the European Union as a group of countries is still the main import origin of African countries.

The two above Figure 5 and Figure 6 demonstrate that China, as a single country is the main trade partner of Africa, and also the importance of China for the African continent since the year 2008, although African exports to China shrank during the years 2015 and 2016.

The figures also show that African countries export more to India than they import.

\section{Imports and Exports Products between China and Africa}

As Africa is known for its abundance of natural resources, the main reason for the Chinese presence in Africa is obviously to seek for natural resources. The following tables tell specifically about the nature of products exchanged between China and Sub Saharan Africa, classified by groups of products and categories of goods.

The observation of Table 2 reveals that from the year 2007 to 2017, $87.85 \%$ of the Chinese imports from Sub Saharan Africa were raw materials, and $9.93 \%$ of intermediate goods mainly used for manufacturing purpose, which indicates the 


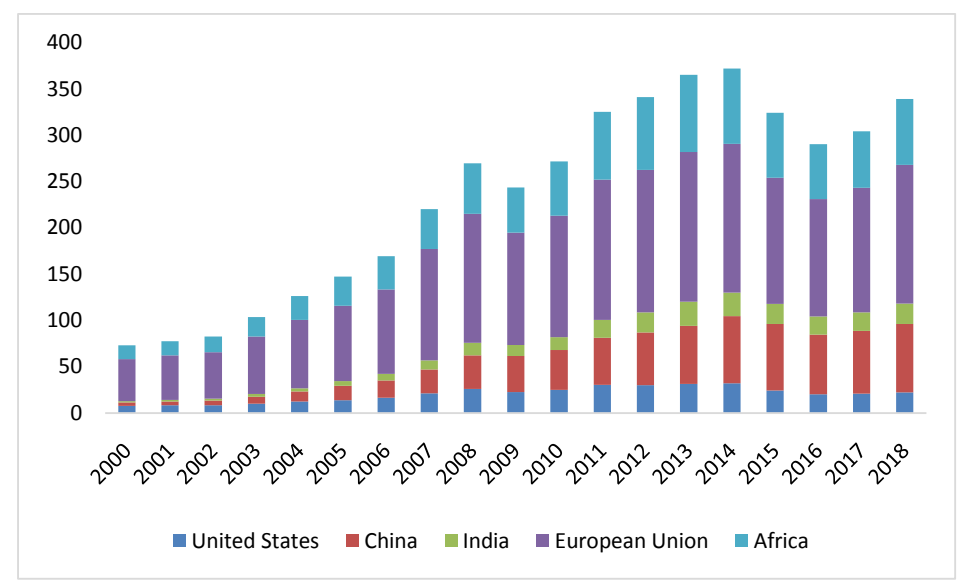

Figure 6. Africa's imports by partner (US\$ Billion). Source: Author's computation of data collected from Direction of Trade Statistics (IMF).

Table 2. Sub Saharan African countries Exports and Imports from Sub Saharan Africa by Groups of Products over the period 2007-2017. The present results indicate the average of the yearly amounts over the period 2007-2017.

\begin{tabular}{ccccc}
\hline $\begin{array}{c}\text { Product } \\
\text { Group }\end{array}$ & $\begin{array}{c}\text { Export } \\
\text { (US\$ Billion) }\end{array}$ & $\begin{array}{c}\text { Import } \\
\text { (US\$ Billion) }\end{array}$ & $\begin{array}{c}\text { Export Product } \\
\text { Share (\%) }\end{array}$ & $\begin{array}{c}\text { Import Product } \\
\text { Share (\%) }\end{array}$ \\
\hline Capital goods & 0.22 & 15.52 & 0.62 & 42.5 \\
Consumer goods & 0.45 & 11.9 & 1.28 & 32.58 \\
Intermediate goods & 3.52 & 8.34 & 9.93 & 22.82 \\
Raw materials & 31.13 & 0.5 & 87.85 & 1.37 \\
All Products & 35.43 & 36.53 & 99.68 & 99.27 \\
\hline
\end{tabular}

Source: Author's computation of data collected from the World Integrated Trade Solution (WITS) database (2019) [21].

level of intra industry trade between China and Sub Saharan Africa. The level of consumer goods is $1.28 \%$ which indicates the difficulty for African final goods to flourish on the Chinese market. Obviously, the level of capital goods is low because China is most likely comparatively advantaged in capital goods. As shown in the table, $42.5 \%$ of the Chinese exports to Sub Saharan Africa from the year 2007 to 2017 are Capital goods, which is confirmed by the multitude of infrastructure and development projects executed by China these recent years in Sub Saharan Africa.

Consumer goods account for $32.58 \%$ of the Chinese exports to Sub Saharan Africa, which is due to the high level of the Chinese manufacturing sector that produces most of the daily used products needed in Sub Saharan Africa. Table 2 shows that consumer goods are the most imported by Sub Saharan Africa from China.

The share of intermediate goods in the Chinese exports to Sub Saharan Africa is $22.82 \%$ sensibly lower than Africa's exports of intermediate goods to China. This tells an acceptable level of intra industry among both sides. Finally, the level of raw materials in the Chinese exports to Sub Saharan Africa is very low 
(1.37\%), which is totally exact, as Africa has a comparative advantage in raw materials.

This table confirms that the China-Africa trade is mainly an exchange of raw materials against manufacturing products. This finding supports the economic theory claiming that countries mostly export what they are abundant in and import what they have no comparative advantage in.

The following tables detail the trade composition between China and Africa.

Figure 7 shows that raw materials are the main exports of Sub Saharan African countries to China. From the year 2009, Sub Saharan Africa exports of raw materials to China worth 30US\$ Billion, kept increasing and reached a peak of 53.7US\$ Billion in 2012 .

The exports of intermediate goods have also increased from 1.5US\$ Billion in 2007 to about 4US\$ Billion in 2017, reaching its peak in 2013 with 4.9US\$ Billion.

The level of consumer goods and capital goods is very low which indicates the difficulty for African countries these products to China, mainly due to the comparative advantage that China has in terms of capital goods and also the difficulty for African products to meet the consumer preferences of the Chinese market.

Figure 8 shows that Sub Saharan African countries import more capital goods than other types of goods. Indeed, African countries have recently experienced impressive infrastructure projects supported by China and promoted by the Belt Road Initiative. The figure also shows that consumer goods occupy an important share of the Sub Saharan African countries imports from China. The imports of intermediate goods from China have increased from 5US\$ Billion in 2007 to 9US\$ Billion in 2017, with a peak of 11.8US\$ Billion reached in the year 2013. This indicates the development of the manufacturing sector in Sub Saharan African countries. The figure also reveals that China exports less raw materials in Sub Saharan Africa, for the reason that Africa is abundant in raw materials.

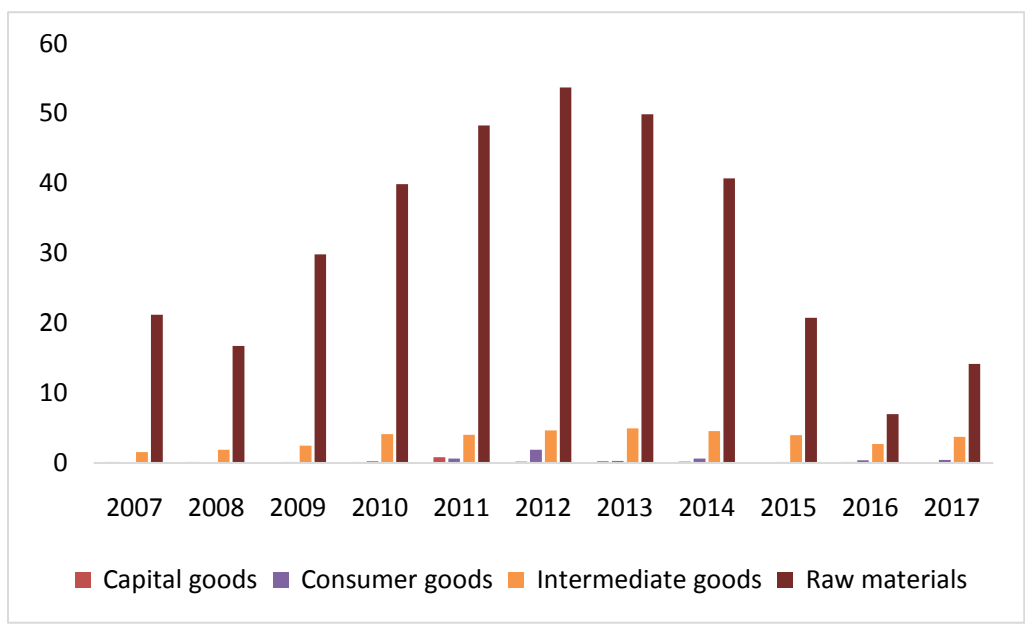

Figure 7. Sub Saharan African countries exports to China from 2007 to 2017 in US\$ Billion. Source: Author's computation of data collected from the World Integrated Trade Solution (WITS) database (2019). 


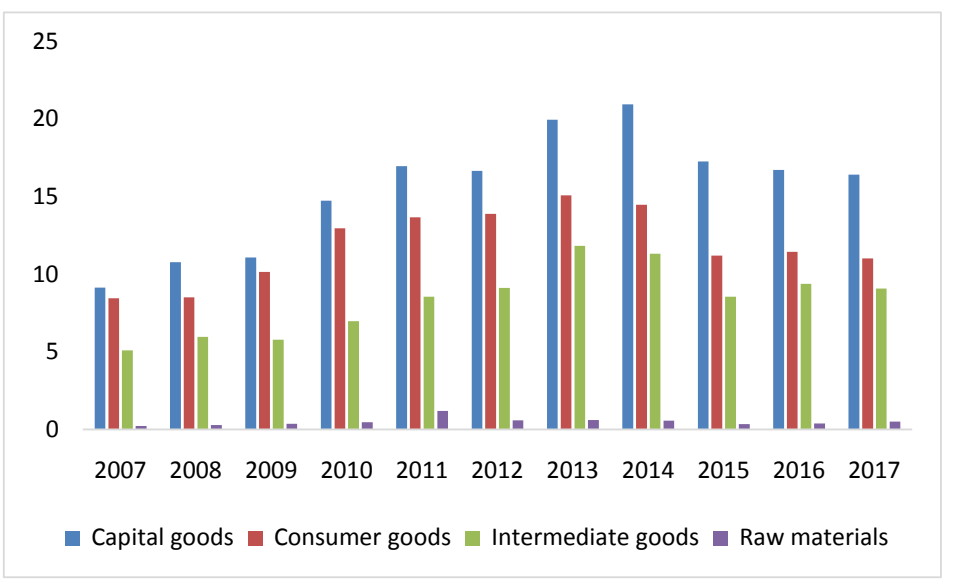

Figure 8. Sub Saharan African countries imports from China from 2007 to 2017 in US\$ Billion. Source: Author's computation of data collected from the World Integrated Trade Solution (WITS) database (2019).

The next table shows the categories of goods exchanged by China and Sub Saharan Africa from the year 2007 to 2017. The results indicate the average value for each product over the same period.

The observation of Table 3 shows the most exports products by China to Sub Saharan Africa over the period 2007-2017 are first, Machinery and Electronic (38.23\%), followed by Textiles and Clothing (8.2\%), then Metals (11.91\%), and Transportation (9.06\%), Plastic or Rubber (5.51\%), Chemicals (6.84\%). The most imported goods by China from Sub Saharan Africa are fuels, accounting for $66.89 \%$, followed by Minerals with $17.44 \%$, at the third position, metals accounting for $7.11 \%$ of the Chinese imports from Sub Saharan Africa. The results of this table are similar to those from the previous table; an exchange of raw materials against manufactured goods is observed, and an equitable exchange in Metals is effectuated, meaning that intra industry trade between China and Africa is mainly processed in the metals industry. Based on these results, we can affirm that China exports mostly Machinery and Electronic to Sub Saharan Africa and imports essentially Fuels from Sub Saharan Africa.

\section{Top African Exporters to China}

As it has been shown previously, China imports mainly raw materials from Africa, which means that the African exporters to China are obviously those rich in raw materials. The following table presents them in details from the year 2011 to 2017.

Table 4 reveals that South Africa is the top African exporter to China, followed by Angola, Congo, DR Congo, and Zambia. According to data from China's Ministry of Commerce (MOFCOM), in 2017, 86.2 percent of South Africa's exports to China were natural resources, specifically base metals and mineral resources.

The table also indicates that South Africa and Angola are the top exporters to 
China in Africa; as shown in the year 2017, the difference is remarkable between their exports to China and the exports of other countries. (24.39 and 20.7 Billion and 3.96 for the third top exporter country which is Congo).

Table 3. Sub Saharan Africa Exports and Imports from China by Categories of Goods over the period 2007-2017.

\begin{tabular}{|c|c|c|c|c|}
\hline Product Group & $\begin{array}{c}\text { Export } \\
\text { (US\$ Billion) }\end{array}$ & $\begin{array}{c}\text { Import } \\
\text { (US\$ Billion) }\end{array}$ & $\begin{array}{c}\text { Export Product } \\
\text { Share (\%) }\end{array}$ & $\begin{array}{c}\text { Import Product } \\
\text { Share (\%) }\end{array}$ \\
\hline Animal & 0.07284 & 0.28675 & 0.21 & 0.79 \\
\hline Chemicals & 0.16109 & 2.49968 & 0.45 & 6.84 \\
\hline Food Products & 0.23201 & 0.54789 & 0.65 & 1.5 \\
\hline Footwear & 0.00576 & 1.10225 & 0.02 & 3.02 \\
\hline Fuels & 23.69875 & 0.20072 & 66.89 & 0.55 \\
\hline Hides and Skins & 0.17612 & 0.30131 & 0.5 & 0.82 \\
\hline Mach and Elec & 0.10754 & 13.96207 & 0.3 & 38.23 \\
\hline Metals & 2.51878 & 4.34958 & 7.11 & 11.91 \\
\hline Minerals & 6.18102 & 0.30818 & 17.44 & 0.84 \\
\hline Miscellaneous & 0.08861 & 2.35229 & 0.25 & 6.44 \\
\hline Plastic or Rubber & 0.26844 & 2.01433 & 0.76 & 5.51 \\
\hline Stone and Glass & 0.30217 & 1.25493 & 0.85 & 3.44 \\
\hline Textiles and Clothing & 0.44167 & 2.99495 & 1.25 & 8.2 \\
\hline Transportation & 0.13786 & 3.30888 & 0.39 & 9.06 \\
\hline Vegetable & 0.45445 & 0.31622 & 1.28 & 0.87 \\
\hline Wood & 0.54745 & 0.71421 & 1.55 & 1.96 \\
\hline All Products & 35.4319 & 36.5258 & 99.89 & 99.97 \\
\hline
\end{tabular}

Source: Author's computation of data collected from the World Integrated Trade Solution (WITS) Database 2019 .

Table 4. Top 10 imports origin of China in Africa in Billion US\$ from 2011 to 2017.

\begin{tabular}{cccccccc}
\hline & 2011 & 2012 & 2013 & 2014 & 2015 & 2016 & 2017 \\
\hline South Africa & 32.1 & 44.65 & 48.39 & 44.57 & 30.15 & 22.23 & 24.39 \\
Angola & 24.92 & 33.56 & 31.97 & 31.11 & 16 & 13.97 & 20.7 \\
Congo & 4.67 & 4.56 & 5.71 & 5.48 & 2.62 & 2.33 & 3.96 \\
DR Congo & 3.16 & 3.53 & 2.75 & 2.81 & 2.63 & 2.08 & 3.29 \\
Zambia & 2.78 & 2.69 & 3.05 & 3.06 & 1.79 & 2.18 & 3.12 \\
Gabon & 0.58 & 0.62 & 0.9 & 1.61 & 1.1 & 1.44 & 2.29 \\
Ghana & 0.36 & 0.64 & 1.2 & 1.45 & 1.3 & 1.31 & 1.85 \\
Nigeria & 1.58 & 1.27 & 1.55 & 2.66 & 1.24 & 0.91 & 1.62 \\
Equatorial Guinea & 1.67 & 1.82 & 2.47 & 3.22 & 1.17 & 0.63 & 1.48 \\
Libya & 2.06 & 6.38 & 2.04 & 0.73 & 0.95 & 0.35 & 1.36 \\
\hline
\end{tabular}

Author's computation of data collected from the International Trade Centre (ITC) Database (2018). 
The structure of the China-trade illustrated by the relationship raw materials for manufacturing goods orientates the Chinese towards countries rich in raw materials, which gives the results observed in the table.

\section{Top African Importers of Chinese Products}

The following table shows the most important importers of Chinese products on the African continent.

The observation of Table 5 shows that South Africa is an African top importer of Chinese products. The second economy of the continent, and the most important trading partner of China in Africa.

The second importer is Nigeria which is obviously caused by the huge population of Nigeria and also purchasing power of the country which is the most economically powerful country in Africa. The third importer is Egypt, which is among the most powerful countries in Africa, with also a high population. The other countries are respectively Algeria, Kenya, Ghana, Morocco, Tanzania, Angola, Ethiopia, they are all economically important in Africa. We can notice that all the best buyers of Chinese products are rich African countries and also possessing a big population which constitutes a huge market for Chinese products.

\section{China's Investments in Africa}

According to The World Investment Report 2018 published by UNCTAD, China's outward FDI flows and stock in 2017 accounted respectively for $11.1 \%$ and $5.9 \%$ of the global total. In terms of FDI flows, China was in third position worldwide [23].

Table 5. Top 10 exports destinations of China in Africa in Billion US\$ from 2011 to 2017.

\begin{tabular}{cccccccc}
\hline & 2011 & 2012 & 2013 & 2014 & 2015 & 2016 & 2017 \\
\hline $\begin{array}{c}\text { South } \\
\text { Africa }\end{array}$ & 13.36 & 15.32 & 16.83 & 15.7 & 15.86 & 12.85 & 14.81 \\
Nigeria & 9.21 & 9.3 & 12.04 & 15.39 & 13.7 & 9.71 & 12.15 \\
Egypt & 7.28 & 8.22 & 8.36 & 10.46 & 11.96 & 10.44 & 9.49 \\
Algeria & 4.47 & 5.42 & 6.02 & 7.4 & 7.58 & 7.65 & 6.78 \\
Kenya & 2.37 & 2.79 & 3.22 & 4.93 & 5.91 & 5.59 & 5.03 \\
Ghana & 3.11 & 4.79 & 3.95 & 4.13 & 5.31 & 4.67 & 4.82 \\
Morocco & 3.04 & 3.13 & 3.27 & 2.96 & 2.9 & 3.08 & 3.18 \\
Tanzania & 1.65 & 2.09 & 3.14 & 3.84 & 4.28 & 3.57 & 3.12 \\
Angola & 2.78 & 4.04 & 3.96 & 5.97 & 3.72 & 1.68 & 2.26 \\
Ethiopia & 0.89 & 1.53 & 1.87 & 2.92 & 3.44 & 3.21 & 2.66 \\
\hline
\end{tabular}

Author's computation of data collected from the International Trade Centre (ITC) Database 2018 [22]. 
During the year 2017, China's investment in Africa reached US $\$ 4.1$ billion, increasing by $70.8 \%$ compared to the precedent year. Africa obtained $2.6 \%$ of total FDI flow in 2017, and the countries which mostly benefited from the investment are Angola, Kenya, Congo (DRC), South Africa, Zambia, Guinea, Congo (Brazzaville), Sudan, Ethiopia, Nigeria, Tanzania, as reported by MOFCOM (2017).

China's outward FDI stock in Africa is evaluated at 2.4\% of the total in 2017, and was mostly benefiting to the following countries: South Africa, Congo (Kinshasa), Zambia, Nigeria, Angola, Ethiopia, Algeria, Zimbabwe, Ghana, Kenya, Tanzania, Sudan, Mauritius, according to the MOFCOM data.

Table 6 and Figure 9 show the share of Africa in the outward investment of China. We notice a very low percentage for either outward FDI flows (2.6\%) or stock (2.4\%), which indicates that other destinations are more attractive to Chinese investment than Africa. These findings are quite paradoxical to the current situation in Africa illustrated by a considerable and increasing number of Chinese entrepreneurs operating on the continent (10,000 Chinese companies and 1.3 million Chinese citizens living in Africa). However, it reveals that most Chinese going to Africa are contractors and don't really establish companies. This situation led the African Development Bank's president, AkinwumiAdesina to ask Chinese companies to invest, rather than contracting or providing loans to the public sector of African countries [25].

The Chinese FDI in Africa has imposingly increased with time. According to data collected from MOFCOM (2018) database, the value foreign direct investment from China in 2004 was 317.43US\$ Million for the whole Africa, while in the year 2017, the value was 4.105US\$ Billion. This change in the value of Chinese investment is considerable, increasing more than 10 times in 13 years, reaching a peak of 5.490US\$ Billion in 2008. Although the increase of Chinese FDI is impressive, it is considered low compared to the investments made by other countries in Africa. According to Howard W. French (2015), China only totalizes roughly 3 percent of the African stock of FDI, which shows that other countries dominate in terms of investments in Africa [26]. On the other hand, the value of the Chinese investments in Africa represented 2.5 percent of the global Chinese investment during the year 2017, getting the smallest share compared to other continents, according to Yun Sun (2018) [27]. In addition, statistics revealed that from the year 2000 to 2015, the Chinese government, banks from China and contractors pledged US $\$ 94.4$ billion worth of loans to African governments and state-owned enterprises, which shows that the Chinese are gradually increasing their investments in Africa [28] (Figure 10).

The Chinese financial commitment to Africa has significantly increased over the years, from $\$ 5$ billion in 2006, $\$ 10$ billion in 2009, $\$ 20$ billion in 2012 and to $\$ 60$ billion in 2015 [27]. In 2018, during the recently held Summit of the Forum on China-Africa Cooperation (FOCAC), China pledged a total of US $\$ 60$ billion to finance projects in Africa as assistance, investment, and loans. These actions 
show the particular interest that China manifests to Africa and in addition, the Belt and Road Initiative also finances development projects in Africa [29].

Table 6. China's Outward Foreign Direct Investment 2017 by regional area (US\$ Billions).

\begin{tabular}{cccc}
\hline Continent & Amount & $\begin{array}{c}\text { Year-on-Year } \\
\text { Growth Rate (\%) }\end{array}$ & Share (\%) \\
\hline Europe & 18.5 & 72.7 & 11.7 \\
Africa & 4.1 & 70.8 & 2.6 \\
Oceania & 5.1 & -1.9 & 3.2 \\
Asia & 110.0 & -15.5 & 69.5 \\
Latin America & 14.1 & -48.3 & 8.9 \\
North America & 6.5 & -68.1 & 4.1 \\
Total & 158.3 & -19.3 & 100.0 \\
\hline
\end{tabular}

Source: Author's computation of data collected from 2017 Statistical Bulletin of China's Outward Foreign Direct Investment (MOFCOM) [24].

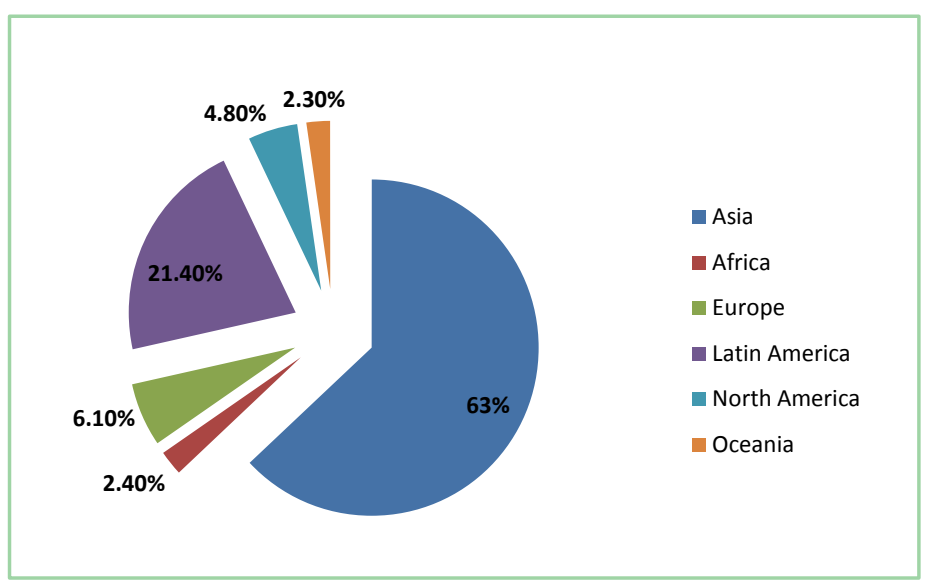

Figure 9. Chinese Outward FDI stock in 2017 by continent. Source: Author's computation of data collected from 2017 Statistical Bulletin of China's Outward Foreign Direct Investment (MOFCOM).

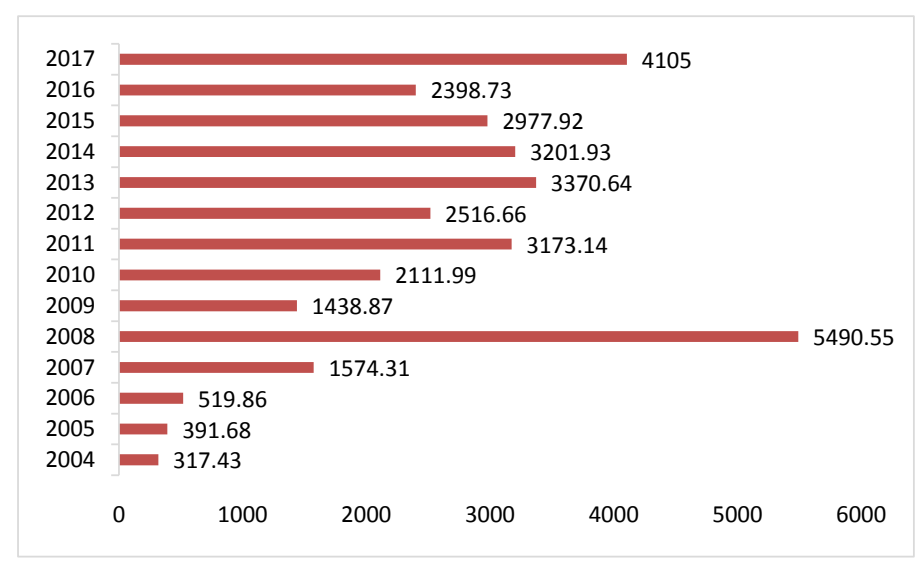

Figure 10. Chinese FDI in Africa in Million US\$ from 2004 to 2017. Source: Author's computation of data collected from 2010 and 2017 Statistical Bulletin of China's Outward Foreign Direct Investment (MOFCOM). 
However, the borrowing capacity of many African countries is shriveling, with an average public debt that has risen from 34 percent of GDP in 2013 to roughly 53 percent in 2017 in sub-Saharan African countries. Angola, Gabon, and Nigeria which are oil-producing countries have their debt service amounts exceeding 60 percent of government revenues. Also, in sub-Saharan Africa, more than 40 percent of low-income countries are declared at high-risk of debt distress [30]. Moreover, China has changed its strategy towards Africa which was initially "resources for infrastructure" to a new approach which is aimed at investing in Africa through Chinese companies and investors that are supported by Chinese development finance institutions. This new approach is promoted by the Chinese government which encouraged Chinese companies to invest a minimum sum of $\$ 10$ billion in Africa in the next three years.

According to International Monetary Fund (IMF) (2015), the growth potential of Africa is perfectly significant, forecasting steady economic growth and social welfare improvement resulting from a demographic boom which could raise GDP per capita by 25 percent by 2050 [31]. This prediction of IMF demonstrates that Africa countries have enough potentialities to attract more investment from China; it now belongs to them to adopt appropriate strategies to achieve their goal.

\section{Chinese Loans to African Countries}

China has recently pledged huge amounts of money to support economic development in Africa. The most recent loan is the impressive pledge of 60US\$ Billion during the FOCAC summit in September 2018 by the Chinese president.

An analysis of the Chinese loans to African countries is conducted based on the China-Africa research initiative (CARI) database of Chinese loans and aid to Africa.

The China-Africa research initiative (CARI) database reveals that from the year 2000 to 2017, China (government, banks, and contractors) lent in the total US\$143 billion to African countries.

The nature of Chinese loans is variant; in some cases, Chinese loans are qualified as "official development aid", in other cases, Chinese loans are export credits and also credits to suppliers.

The observation of Figure 11 shows a considerable evolution of Chinese loans in Africa. The Chinese loans in Africa have gradually increased from 130 US\$ Million in 2000 to the pick of 30US\$ Billion in 2016. This impressive growth of the Chinese loans in Africa reflects the interest of China for Africa and also demonstrates the good relationship existing between China and the African countries.

\section{Top 15 African countries acquiring Chinese loans and investment}

The following table illustrates the top 15 African countries contracting Chinese loans from the year 2000 to 2017, and top 15 African countries attracting the Chinese investment. 


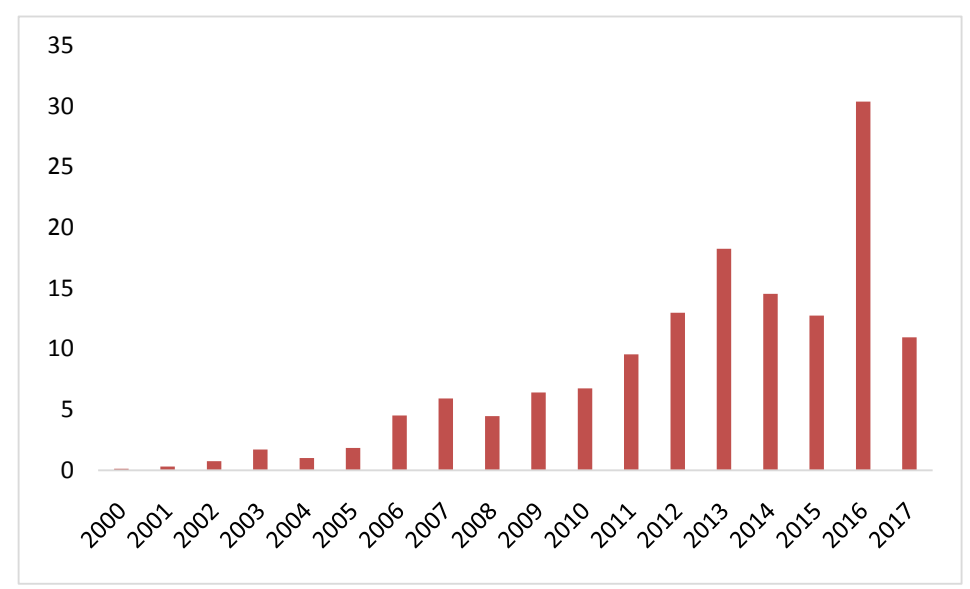

Figure 11. Chinese loans to African countries from 2000 to 2017 in US\$ Billion. Source: Author's computation of data collected from the China-Africa research initiative (CARI) Database [32].

The loans from China were calculated by the sum of the total loans obtained by the countries from the year 2000 to 2017. The data were collected from the CARI database 2019, while the FDI flow is the total sum of Chinese investment by country from the year 2003 to the year 2017. The data were collected from the Statistical Bulletin of China's Outward Foreign Direct Investment (MOFCOM).

Table 7 indicates that 15 African countries out of 53 totalize $83 \%$ of the Chinese loans, with Angola in the first position with $29.89 \%$ of the total amount of loans given by China between the years 2000 and 2017. Ethiopia follows with 9.58\%, then Kenya (6.84\%) and Congo (5.18).

On the other side, the top 15 African countries account for $80 \%$ of the Chinese FDI flow, led by South Africa with $19.04 \%$ of the total FDI over the period 2003-2017. Nigeria has the second position with $7.74 \%$, followed by Zambia (7.55\%), DRC (6.65\%), Algeria (6.4\%) and Sudan (5.28\%).

The study reveals that the China-Africa trade relationship has considerably evolved over the years. Most African countries increased their trade with China either through infrastructure projects, imports of manufactured goods or raw materials exports which contributed to the galloping presence of Chinese in Africa.

The study specifically highlighted some African countries that remarkably collaborated with China. Based on the analysis of the data presented previously, South Africa which is the second economy of Africa appears as the biggest importer and exporter to China among African countries from 2011 to 2017, and also the first destination of Chinese FDI in Africa with $19.04 \%$ of the total investment made by China in Africa from 2003 to 2017.

Nigeria which is the first economy of the African continent is also the second important trade partner of China in Africa. It is the second biggest importer of Chinese products and also the second destination of Chinese investment in Africa with $7.74 \%$ of the total Chinese FDI flow. 
Table 7. Top 15 African countries for Chinese loans and investment in US\$ Billion.

\begin{tabular}{ccccccc}
\hline No. & Country & Loans & $\begin{array}{c}\text { Loans } \\
\text { share }(\%)\end{array}$ & Country & FDI flow & $\begin{array}{c}\text { FDI } \\
\text { share }(\%)\end{array}$ \\
\hline 1 & Angola & 42.85 & 29.89 & Algeria & 16.28 & 6.4 \\
2 & Cameroon & 5.57 & 3.88 & Angola & 10.4 & 4.08 \\
3 & Congo & 7.42 & 5.18 & Congo & 5.8 & 2.28 \\
4 & Cote d'Ivoire & 2.69 & 1.88 & DRC & 16.92 & 6.65 \\
5 & DRC & 3.44 & 2.4 & Egypt & 5.47 & 2.15 \\
6 & Egypt & 3.42 & 2.39 & Ethiopia & 8.85 & 3.48 \\
7 & Ethiopia & 13.74 & 9.58 & Ghana & 7.99 & 3.14 \\
8 & Ghana & 3.5 & 2.44 & Kenya & 6.58 & 2.58 \\
9 & Kenya & 9.8 & 6.84 & Mauritius & 6.94 & 2.73 \\
10 & Nigeria & 4.83 & 3.37 & Nigeria & 19.7 & 7.74 \\
11 & South Africa & 3.78 & 2.64 & South Africa & 48.48 & 19.04 \\
12 & Sudan & 6.49 & 4.53 & Sudan & 13.43 & 5.28 \\
13 & Tanzania & 2.35 & 1.64 & Tanzania & 7.29 & 2.86 \\
14 & Uganda & 2.97 & 2.07 & Zambia & 19.21 & 7.55 \\
15 & Zambia & 6.38 & 4.45 & Zimbabwe & 10.57 & 4.15 \\
Total & & 143.35 & 83.18 & & 254.56 & 80.11 \\
\hline
\end{tabular}

Source: Author's computation of data collected from the China-Africa Research Initiative (CARI) database.

Angola is an essential partner for China in Africa; the country is the second biggest exporter to China, also the first beneficiary of Chinese loans in Africa with $29.89 \%$ of the total amount of loans granted by China over the period 2000-2017. Angola is also among the top 15 importers of Chinese products in Africa and attracted $4.08 \%$ of the total Chinese FDI on the African continent from 2003 to 2017.

Egypt is the third importer of Chinese products in Africa and among the top 15 Chinese loans and FDI recipients in Africa. It is also among the most developed African countries and important partners of China in Africa.

Some countries such as Zambia, Congo, and DRC are raw materials providers for China which stimulated loans and investments from China into these countries.

\section{Recommendations}

The development of intra industry trade with China is primordial to African countries which are abundant in raw materials and economically led by the trade of agriculture products. Intra industry trade ensures the creation of more value-added from raw materials in which African countries are abundant. The transformation of intra industry trade level will be done through the transformation of its raw materials, particularly the transformation of agriculture products 
which are what local people can directly consume and require light manufacturing level.

In this perspective, China appears to be a good interlocutor, with its developed manufacturing sector and also high machinery production levels. Due to the technological gap, access to the Chinese market seems difficult for African products apart from raw materials. In such a case, African countries should import light manufacturing machinery to foster the transformation of agricultural products necessary for countries' food self-sufficiency. Moreover, further cooperation should be planned for the sake of acquiring more machinery and technology needed to improve agriculture performance and also enable the transformation of the variety of agriculture products abundantly available on the African continent.

Also, the diversification of export destinations has to be effective in the African countries that highly rely on exporting to China, reaching more than $50 \%$ of their total export for some of them. Diversifying the export partners will reduce the dependence on China and avoid eventual negative consequences that can occur in case of demand decrease. The diversification can be done through the Intra African Trade. Indeed, the African continent constitutes a very big market with its dense population which is estimated to exceed 2 billion inhabitants by 2040 [33].

Promoting intra African trade is nowadays a must for African countries in order to depend on themselves and not long in developed countries. As mentioned by The World Bank (2015), greater trade integration between African countries leads to poverty reduction which is also the goal of the international institution [34]. Furthermore, the recently born African Continental Free Trade Area (AfCFTA) signed by 44 African countries aiming to bring over 1.2 bn people together into a common market is a great initiative. African leaders are therefore encouraged to ensure its effectiveness and full operation including the totality of the 55 African countries making it the world's largest free trade area by member states and its definitely envisaged to lead Africa to better-living conditions and undoubtedly economic prosperity.

\section{Conclusions}

The China-Africa-trade relationship which deepened in the year 2000 has become so productive for both African and Chinese sides. China is today an essential trade partner of Africa, which contributes considerably to the development of African countries.

China mostly exports consumer goods, intermediate goods and also capital goods to Africa and imports raw materials and natural resources form African countries. In fact, in recent years, trade between China and Africa contributed to $20 \%$ of the economic growth of Africa [10].

South Africa is the biggest trade partner of China in Africa; it is the top importer of Chinese products and also the top exporter to China. Indeed, South 
Africa is the largest African country exporting to China, followed by Angola, Congo, DR Congo, and Zambia, and also the largest importer of Chinese products, followed by Nigeria, Egypt, and Algeria, Kenya, Ghana, Morocco, Tanzania, Angola, Ethiopia which are also among the richest countries of Africa. The China-Africa trade balance is favorable to China mainly due to the dependence of Africa's economy on raw materials which generated a large deficit caused by the decrease in commodity prices on international markets.

South Africa is also the most attractive country for Chinese investment in Africa followed by Nigeria and Zambia, while Angola is the largest beneficiary of Chinese loans among African countries.

The contribution of China to the development of Africa is very effective and prolific. Indeed, in recent years, China has impressively invested in infrastructures and several other development projects, such as energy, education, health, which significantly improved the welfare of the African population.

However, there is still more to do for China to become indispensable to Africa's development; for instance, the Chinese investment in Africa which has increased recently but is low compared to the investments of other countries in Africa. The Chinese entrepreneurs in Africa are told to contract seekers and loans providers instead of operating and competing on the African market.

Furthermore, scholars believe that infrastructure and manufacturing are two key economic drivers that will boost the economic development of African countries and facilitate their access to the international value chain that will really be a take-off for the African continent.

Meanwhile, Africa also faces many challenges which are social and political instability, unemployment, terrorism. These problems have to be solved for better cooperation with partners in order to improve the development of Africa which is full of potentialities.

\section{Conflicts of Interest}

The author declares no conflicts of interest regarding the publication of this paper.

\section{References}

[1] Workman, D. (2019) China's Top Trading Partners.

[2] Maswana, J.-C. (2018) Revisiting the Growth Effects of Sino-African Bilateral Trade on African Economies.

[3] Monaghan, A. (2014) China Surpasses US as World's Largest Trading Nation. The Guardian.

[4] Xinhua (2018) China-Africa Economic and Trade Cooperation.

[5] Chitsa, T. (2018) Africa: Focac-China-Africa Ties Set to Grow. The Herald.

[6] AfriqueMonAfrique (2018) China Pledges \$60 Billion for Africa’s Development.

[7] China Daily (2017) African Countries Hope to Attract More Chinese Investments.

[8] Nizard, R. (2017) China-Sub-Saharan Africa Trade Relations: Still Unbalanced. Co- 
face.

[9] Crisafulli, G. (2018) China-Africa Trade to Benefit from Growing Economic Cooperation. China Briefing.

[10] Romei, V. (2015) China and Africa: Trade Relationship Evolves. Financial Times.

[11] Hai, H. and Cohen, A. (2017) China Is Africa's Biggest Economic Partner, But What Role for the United States? Forbes Opinion.

[12] Zheng, Y. (2016) China's Aid and Investment in Africa: A Viable Solution to International Development?

[13] Xinhua (2017) Major China-Africa Infrastructure Cooperation Projects. Chinadaily.com.

[14] Said, H. (2018) China's New Development Approach in Africa. China.org.cn.

[15] Ayodele, T. and Sotola, O. (2014) China in Africa: An Evaluation of Chinese Investment Initiative for Public Policy Analysis (IPPA) 2014.

[16] Zheng, Y. (2019) China-Africa Economic, Trade Cooperation Forges on. China Daily.

[17] China Economic.net (2019) Chinese Companies in Africa Create Great Development Opportunities.

[18] Xinhua (2017) China Focus: Chinese Fund Helps Development in Africa.

[19] Direction of Trade Statistics (DOTS) (2019) International Monetary Fund (IMF).

[20] China-Africa Research Initiative (2018) Data: China Africa Trade.

[21] World Integrated Trade Solution (WITS) Database (2019).

[22] International Trade Centre (ITC) Database (2018).

[23] World Investment Report 2018: Investment and New Industrial Policies, UNCTAD.

[24] Statistical Bulletin of China's Outward Foreign Direct Investment (MOFCOM) 2017.

[25] African Development Bank (2018) “Africa Is the Place to Be”, African Development Bank President Tells Chinese Business Leaders at the China-Africa Forum.

[26] French, H.W. (2015) China's Second Continent: How a Million Migrants Are Building a New Empire in Africa. Vintage Books, New York.

[27] Sun, Y. (2018) China's 2018 Financial Commitments to Africa: Adjustment and Recalibration (Brookings).

[28] Chen and Nord (2018) China and Africa: Whither the Belt and Road? International Centre for Trade and Sustainable Development, Bridges Africa, Analysis and News on African Trade and Sustainable Development.

[29] Brautigam, D. (2018) China's FOCAC Financial Package for Africa 2018: Four Facts, China Africa Research Initiative.

[30] Monteiro, A. (2018) Rising Africa Debt Distress Risks Economic Recovery, IMF Says, Bloomberg.

[31] Regional Economic Outlook (2015) Sub Saharan Africa Dealing with the Gathering Clouds. International Monetary Fund (IMF), Washington DC.

[32] China-Africa Research Initiative (CARI) (2019) Data: Chinese Loans to Africa.

[33] Worldometers (2019) African Population.

[34] The World Bank (2015) Deepening African Integration: Intra-Africa Trade for Development and Poverty Reduction. 